\title{
LA RESTAURACIÓN DEL CRUCERO Y LA ERMITA DE LA CONCEPCIÓN EN ENCISO (LA RIOJA): UN EJEMPLO DE COLABORACIÓN INTERDISCIPLINAR
}

\author{
Rosana Foncea López \\ Minerva Sáenz Rodríguez \\ Universidad de La Rioja
}

RESUMEN: La restauración del crucero y la ermita de la Concepción en Enciso se hizo realidad tras un proceso desarrollado entre los años 2005 y 2008 que, además del proyecto de intervención arquitectónica, incluyó otra serie de trabajos: un estudio histórico-artístico y una supervisión arqueológica, así como las restauraciones del empedrado original del pavimento interior y de las pinturas murales aparecidas durante el proceso rehabilitador. Esta experiencia es un ejemplo más de cómo la colaboración de un equipo multidisciplinar es muy beneficiosa para resolver satisfactoriamente las dudas que se plantean en los procesos de recuperación de un inmueble.

El conjunto monumental se compone de un crucero con templete o humilladero, datado a comienzos del siglo XVI, y de una ermita adosada al mismo, de calidad arquitectónica más modesta, construida inmediatamente después y reformada en los siglos XVIII y XIX. En este artículo, que es una síntesis del estudio histórico-artístico, se analiza la evolución histórica del monumento, su cronología y sus principales características tipológicas y constructivas.

Palabras clave: Enciso, valle del Cidacos, Rioja Baja, restauración, ermita, crucero, humilladero, arquitectura religiosa, escultura, pintura, escudo, nobleza, siglo XVI, estilo Gótico tardío, estilo Reyes Católicos, estilo hispanoflamenco, Renacimiento.

\section{THE RESTORATION OF THE TRANSEPT AND THE HERMITAGE OF LA CONCEPCIÓN IN ENCISO (LA RIOJA): AN EXAMPLE OF INTERDISCIPLINE COLLABORATION}

ABSTRACT: The restoration of the transept and the hermitage of La Concepción in Enciso was produced after a process between the years 2005 and 2008; in 
addition of the project of the archaeological intervention, there are other works as a historic and artistic studio and an archaeological supervision; also the restoration of the original paving of the indoor flooring and the wall paintings which appeared during the rehabilitation process. This experience is one of the examples of collaboration of a multidiscipline team and it's very useful to solve properly the posed problems during the restoration.

The monumental composition is formed by a transept with a templete from the $\mathrm{XVI}$ century, and a hermitage leant it up which is more modest as architectural quality and it was built immediately after. It was improved in the XVIII and XIX centuries. In this article, which is a summary of the historic and artistic studio, it analyses the historic evolution of the monument, its chronology and its main characteristics not only typological but also constructive.

Keywords: Enciso, the Cidacos Valley, Rioja Baja, restoration, hermitage, transept, templete, religious architecture, sculpture, painting, property, coat of arms, nobility, XVI century, late Gothic style, the Catholic Monarchs style, the Spanish-Flemish style, Renaissance.

\section{El edificio y el proyecto de restauración}

El conjunto monumental que en Enciso integra la ermita de la Concepción y el crucero con templete o humilladero, adosado en su lado oriental, se asienta en una pequeña planicie o altozano a las afueras del pueblo, a medio kilómetro de él aproximadamente, en su extremo sur, sobre la curva de la carretera que conduce a Arnedo (LR-115). Enfrente se ubica un puente también Ilamado de la Concepción (Lám. 1).

La restauración de este conjunto patrimonial comenzó a plantearse en los años noventa del siglo XX. La primera solicitud para obtener una subvención que permitiera Ilevar a cabo dicha rehabilitación la realizó el Ayuntamiento de Enciso en 1998 al Gobierno de La Rioja. En ese momento solo se tenía la intención de reparar las cubiertas bajo la dirección técnica del aparejador Francisco Bermejo Donamaría'. En 2005 fue el Grupo de Acción Local La Rioja Suroriental quien volvió a interesarse por la ermita buscando apoyos a través del Programa Leader Plus, pero se rechazó la propuesta por considerar que el Programa solo podía financiar proyectos relacionados con el entorno de las edificaciones, excluyendo a las mismas².

1. Archivo Municipal de Enciso. En adelante, AME. Hacienda. Financiación. Expedientes. Expediente de solicitud de subvención para las obras de restauración de la cubierta de la ermita de Nuestra Señora de la Concepción. 1998. ENCI/194/15.

2. AME. Hacienda. Financiación. Expedientes. Expediente de subvención para las obras de restauración de la ermita y crucero de la Concepción. 2005-2006. ENCl/197/04. 


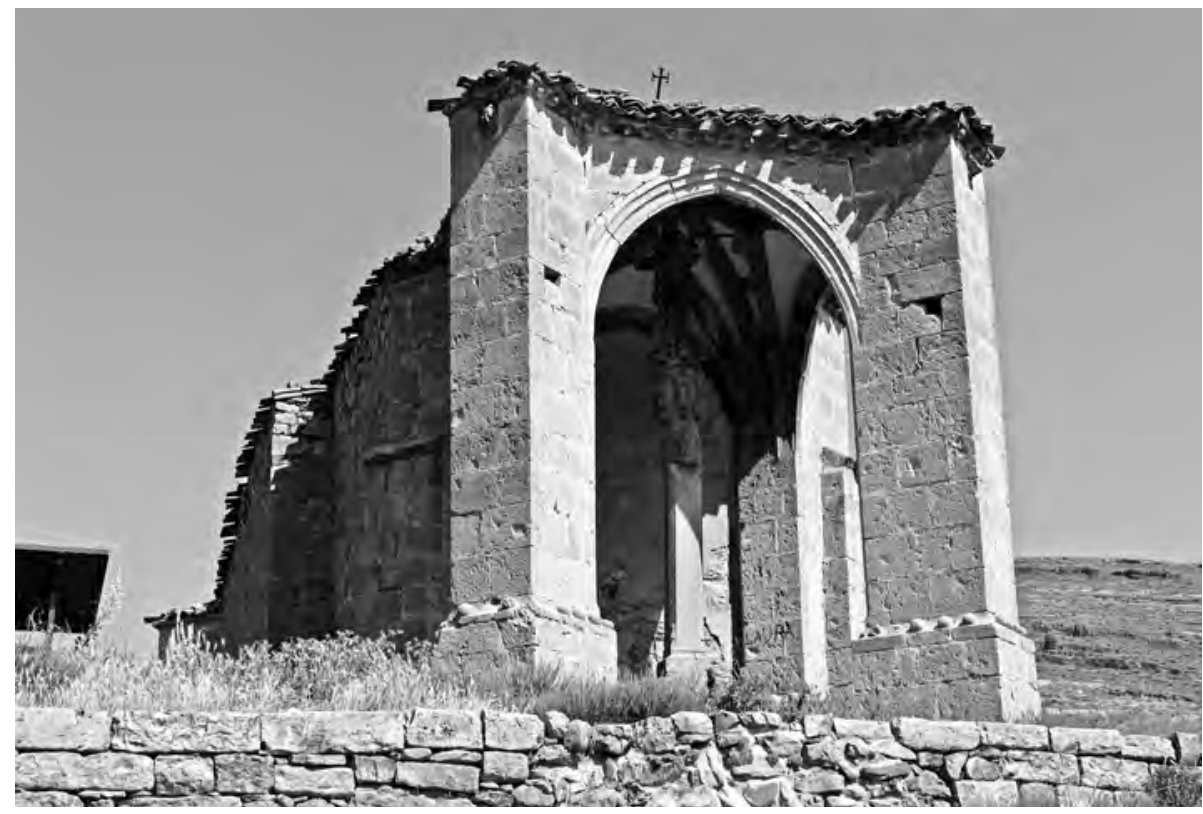

Lámina 1. Vista oriental del crucero y la ermita de la Concepción en Enciso antes de su restauración. Foto Minerva Sáenz.

Fue a partir del año 2007 cuando se dio forma al proyecto definitivo que pondría fin al grave deterioro del monumento. El crucero adosado a la ermita de la Concepción en Enciso se encuentra dentro de la categoría de Bien de Interés Cultural y, consecuentemente, aunque no posea la declaración expresa, por ley goza de la máxima protección. El Ayuntamiento, consciente de la importancia del monumento y de su marco de protección, firmó un Convenio con la Consejería de Cultura, con proyecto técnico elaborado por el arquitecto Óscar Reinares Fernández . Las obras se desarrollaron entre 2007 y 2008 (Lám. 2) de forma paralela al informe histórico-artístico, encargado por el citado arquitecto y redactado por las autoras de este artículo, realizándose de forma coordinada con el equipo técnico que intervino en la obra: José Manuel Valle Melón, autor del levantamiento topográfico, Beatriz Irulegui Blasco, arqueóloga encargada de la supervisión arqueológica y de la lectura mural, y María Mena Miguel, restauradora de las pinturas del interior.

3. AME. Servicios. Obras y urbanismo. Expedientes de obras municipales. Obras de rehabilitación: Proyecto de obras de restauración de la ermita y crucero de la Concepción. 20052006. ENCI/197/04. REINARES FERNÁNDEZ, Ó., Proyecto de ejecución para las obras de restauración de la ermita y crucero de la Concepción en Enciso (La Rioja). Logroño, 2005. 


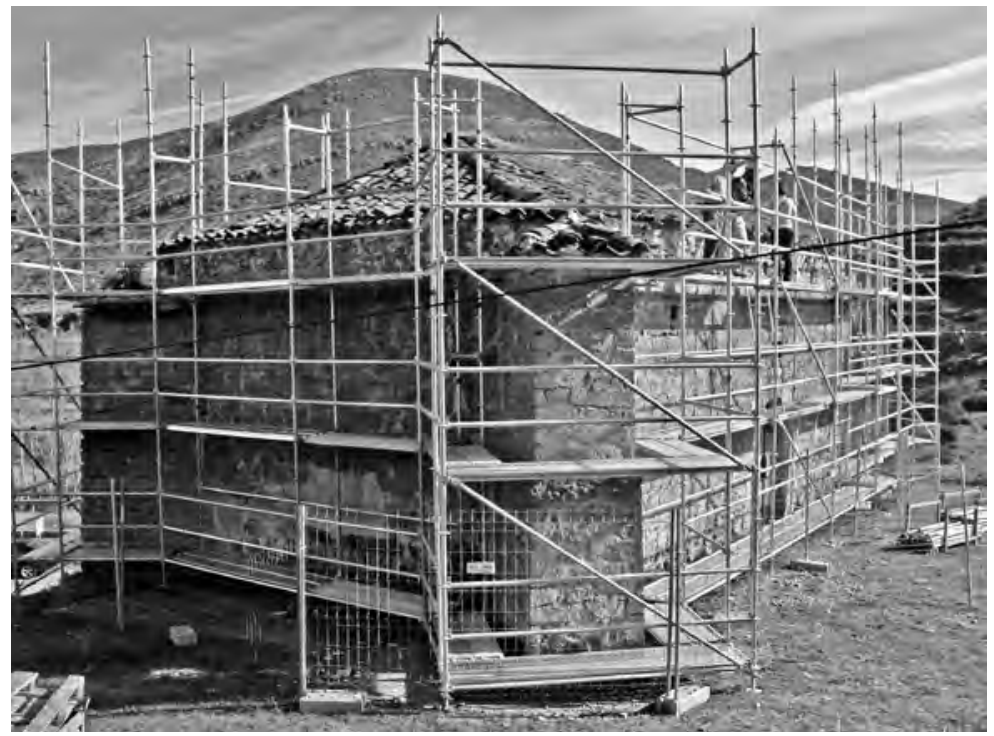

Lámina 2.

Vista occidental de la ermita durante su restauración. Foto Óscar Reinares.

En el cometido de la investigación histórica se contempló la revisión de las fuentes documentales y de la bibliografía existente para establecer la evolución histórica del edificio y el proceso constructivo desde sus orígenes hasta nuestros días. Asimismo, se hizo la descripción de los restos arquitectónicos de interés del inmueble, analizando sus espacios e incidiendo en su estudio estilístico y en los problemas cronológicos que planteaba, debido a la existencia de diferentes estructuras constructivas y a la ausencia de fuentes documentales que aporten datos concretos sobre las mismas.

Dado el mal estado en que se encontraban los elementos estructurales y ornamentales del crucero y ermita, el proyecto arquitectónico planteó una restauración integral para asegurar su conservación. Antes de intervenir en las cubiertas fue preciso resolver el problema de distribución de cargas de las bóvedas y la consiguiente deformación del arco triunfal. Aunque el propio crucero estaba recto, la bóveda del humilladero que se eleva por encima se encontraba totalmente desviada hacia la cabecera de la ermita, y las abrazaderas de hierro que la sujetaban estaban partidas, pues la cumbrera del tejado apoyaba directamente sobre el vértice del templete, empujándolo hacia el exterior. La intervención, por tanto, incluyó la renovación completa de la cubierta del inmueble, la limpieza y consolidación de los paramentos interiores y exteriores y, por último, la restauración integral de la escultura del crucero, cuyos óptimos resultados pueden contemplarse en la actualidad. Cabe destacar la labor del equipo multidisciplinar al que nos hemos referido, para resolver satisfactoriamente las dudas que planteaba el edificio en su concepción, técnica constructiva, procesos de deterioro y alteraciones que le afectaron en el tiempo. 


\section{Revisión historiográfica y fuentes documentales}

Del conjunto monumental formado por el crucero y la ermita de la Concepción en Enciso apenas existe bibliografía. Solo se describe en algunas obras en cuya redacción participó José Gabriel Moya Valgañón y en un artículo de prensa de F. J. Ignacio López de Silanes Valgañón ${ }^{4}$.

Los datos documentales publicados referentes a Enciso apenas aportan datos concretos sobre estos monumentos. En el Libro de Visita del licenciado Martín Gil, datado en 1556, se cita la Concepción pero solo como cofradía, no como ermita: "Yten que ay seys hermitas; son N [uest] ra Señora del Campo, Sanct Antolino, San Juan, La Madalena Sant Esteban y San Chr[ist]óbal; no hay rrenta. Yten que ay seis confradías: de N[uest]ra Señora y San P[edr]o y de Santa Luzía, y San Bartolomé y de la Conçebçión y de San[ta] Çeçilia; no tienen rrenta"5.

En otro documento publicado, fechado el 17 de abril de 1641, conservado en el Archivo Histórico Nacional, en el que se narra un hecho milagroso relacionado con la patrona de la localidad, la Virgen de la Estrella, se mencionan las dos iglesias más importantes, la de Santa María de la Estrella y la de San Pedro, además de algunas ermitas, como la de San Andrés Apóstol (desaparecida) y la de la Purísima Concepción, ambas con humilladeros junto a sendos puentes, y las de Nuestra Señora del Campo y Santa Bárbara, las dos situadas extramuros, en el camino del Vía Crucis ${ }^{6}$. Lo que nos interesa se expresa así:

La dicha villa es muy antigua y esta çercada, para mas ostentación de su antiguedad, junto a ella, arrimado a sus muros, pasa el dicho rio y en el ay dos famossas puentes labradas con toda atencion. $Y$ en la primera puente esta un humilladero y una hermita de San Andres apostol, labrados de piedra de silleria fornossa y, en esta correspondencia, en la segunda puente esta otro humilladero y una hermita de la Purisima Conçepcion de la Vir-

4. MOYA VALGAÑÓN, J. G., RUIZ EZQUERRO, J. J., Enciso monumental. "Biblioteca de Temas Riojanos", Logroño, Gonzalo de Berceo, IER, 1975, pp. 82-89. MOYA VALGAÑÓN, J. G. (Dir.), y otros, Inventario artístico de Logroño y su provincia. Tomo II: Cenicero-Montalbo en Cameros. Madrid, Ministerio de Educación y Ciencia, 1976, p. 102. LÓPEZ DE SILANES VALGAÑÓN, F. J. I., "Ermitas de la Virgen del Campo y de la Concepción, y el Castillo. Enciso medieval". La Rioja Domingo, 1-junio-1997, pp. VI-VII. MOYA VALGAÑÓN, J. G., "El siglo XVI. El Renacimiento. Arquitectura religiosa" en MOYA VALGAÑÓN, J. G. (Dir.), ARRÚE UGARTE, B. (Coord.), Historia del Arte en La Rioja. El siglo XVI. Vol. III, Logroño, Fundación Cultural Caja Rioja, 2007, pp. 83-180 (alusión a la Concepción en p. 153).

5. Libro de Visita del Licenciado Martín Gil. Introducción, transcripción y notas de Pablo DÍAZ BODEGAS. Logroño, Diócesis de Calahorra y La Calzada-Logroño, 1998, p. 35. SOLANO ANTOÑANZAS, J. M. a El valle del Cidacos (cuenca del Ebro). Vol. II. Los afluentes desde el nacimiento del río Cidacos, sus acequias, barrancos, arroyos, embalses o pantanos, molinos, fuentes, etc., con sus poblaciones y nacimientos. Calahorra, autor-editor, 1998, p. 158.

6. ÁlVAREZ CLAVIJO, M. a T., "La Virgen de la Estrella de Enciso (La Rioja)". Berceo, núm. 132, Logroño, IER, 1997, p. 58. 
gen Santisima, labrados de la mesma forma, de modo que dichos edificios, de puentes humilladeros y hermitas, estan con tal arte y corresspondencia ygual, que causan admiracion ${ }^{7}$.

Estos conjuntos monumentales también se citan a finales del siglo XVIII con motivo de un cuestionario que el geógrafo regio Tomás López envió a todos los pueblos de nuestro país, pues proyectaba publicar unas Relaciones Topográficas de España, especie de Diccionario Geográfico que no llegó a realizar. Aunque muy pocos pueblos de La Rioja respondieron el citado cuestionario, uno de ellos fue el de Enciso, en el que constaban, entre otras, las ermitas de San Andrés y de La Concepción ubicadas junto a sendos puentes ${ }^{8}$.

Como ambas ermitas con sus humilladeros se ubicaban al principio y al final de la población, es posible que los dos cruceros originalmente se concibieran como cruces de término. Actualmente solo se conserva el conjunto integrado por el crucero, ermita y puente de la Concepción?. Lo de San Andrés no ha llegado a nuestros días, y en el pueblo no se conserva ninguna memoria de ello, de lo que se deduce que tuvo que desaparecer hace mucho tiempo. En un manuscrito conservado en el Instituto de Estudios Riojanos se cita esta ermita como una de las que eran alumbradas a costa de las parroquias del pueblo y, sin embargo, se omite la de la Concepción ${ }^{10}$.

La mayoría de los datos de los archivos, inevitablemente, se han perdido. De ello también informaba a finales del siglo XVIII Tomás López en su cuestionario $^{11}$. De su testimonio se deduce que en el siglo XVII el Archivo Parroquial fue asaltado y, probablemente, robado.

En el Archivo Histórico Diocesano ubicado en Logroño (AHDLO), se encuentran los Libros de Fábrica de la Estrella donde encontramos algunas alusiones a

7. ÁlVAREZ CLAVIJO, M. ${ }^{a}$ T., op. cit., p. 72. El documento se encuentra en el AHN: Inquisición, leg. 4.589/1. S. f. También lo cita HERGUETA y MARÍN, N., Descripción geográfico-histórica de los pueblos de la provincia de Logroño pertenecientes al obispado de Calahorra. T. I (A-J). Copiado por Narciso Hergueta del Diccionario Geográfico, estadístico, histórico, biográfico, postal, municipal, militar, marítimo, y eclesiástico de España y sus posesiones de ultramar, publicado bajo la dirección de RIERA y SANS, Pablo, Imp. del Heredero de Riera, 1881-1887. 12 vols. Archivo IER, M/308.

8. LOPE TOLEDO, J. M. ‥ " "Relaciones topográficas de La Rioja". Berceo, 10, Logroño, IER, 1949, pp. 103-104, 99-106.

9. El puente de la Concepción es de tradición medieval, pero fue ejecutado ya en el siglo XVI y reformado en el XVIII. Tiene un arco de medio punto algo rebajado sin tajamares ni espolones y tablero con perfil alomado que conserva su calzada original empedrada con cantos rodados. ARRÚE UGARTE, B., MOYA VALGAÑÓN, J. G. (Coord.), Catálogo de puentes anteriores a 1800. La Rioja. I. Logroño, IER, Ministerio de Fomento, 1998, pp. 580-582.

10. ROMERO, F., "Datos sobre la Virgen de la Estrella, venerada en la villa de Enciso", 1932. Manuscrito autógrafo inédito, Archivo IER, M/296.

11. LOPE TOLEDO, J. M. ․, op. cit., p. 99. 
la ermita, con referencias a su estado y a la necesidad de realizar determinadas obras, como se explica en el apartado del proceso constructivo. La ermita dependía de Santa María de la Estrella, así como el resto de ermitas de la localidad: San Juan Bautista, San Andrés, Santa Bárbara, Nuestra Señora del Campo, San Cristóbal y San Esteban. Las referencias encontradas corresponden a las indicaciones que hacía el visitador del obispado en su recorrido periódico por los edificios religiosos de la jurisdicción. Sin embargo, sobre la ermita y crucero de la Concepción no hallamos noticias de gastos concretos o nombres de posibles artífices que hubieran realizado obras, si bien esa clase de noticias abundan para referirse a otros edificios, especialmente a la ermita de San Esteban, hoy en ruinas.

En el Archivo Histórico Provincial de La Rioja (AHPLR) se hallan escrituras de obras de otras construcciones religiosas de Enciso entre finales del siglo XVI y a lo largo del siglo XVII, como son las dos importantes iglesias de Santa María de la Estrella y de San Pedro, y con una lista de nombres de canteros, escultores y pintores doradores de retablos que trabajaban en Enciso en dichos templos. No obstante, como se verá, de la documentación consultada en los Protocolos Notariales se ha podido extrapolar alguna información. El protocolo más antiguo de Enciso conservado aquí es del año 1562, excluyéndose, por tanto, la existencia de documentación acerca del levantamiento y de los artífices de la ermita y crucero, pues, como sabemos, para esa fecha Nuestra Señora de la Concepción ya estaba construida. El Catastro del Marqués de la Ensenada tampoco alude a la Concepción debido a que esta ermita a mediados del siglo XVIII no tenía bienes adscritos a ella ni rentas.

Una mención aparte merece el Archivo de los Duques de Medinaceli (ADM), debido a la relación histórica de este linaje con la población de Enciso, constatada a través de la escasa documentación publicada. En los archivos Diocesano de Calahorra (ADC) y Municipal de Enciso (AME) las escasas noticias aportan datos muy tardíos, concretamente del siglo XIX en el primero de estos archivos -Sección de Estadísticas del Arciprestazgo de Arnedo-, y en el segundo entre los años 1998 y 2005, sobre los expedientes de los proyectos de restauración de la ermita.

\section{Descripción del crucero}

El crucero con templete de Enciso se halla adosado al lado este de la ermita de la Concepción, la cual constituye una prolongación del mismo ${ }^{12}$. Por su

12. Este monumento se cita en MOYA VALGAÑÓN, J. G., RUIZ EZQUERRO, J. J., Enciso monumental, op. cit., pp. 82-89. MOYA VALGAÑÓN, J. G. (Dir.), y otros, Inventario artístico de Logroño y su provincia. Tomo II: Cenicero-Montalbo en Cameros. op. cit., pp. 102, 103. ABAD LEÓN, F., "Geografía Mariana de La Rioja". Berceo, 89, Logroño, IER, 1975, p. 203. MARTíN LOSA, F. (Dir.), y otros, Enciclopedia de La Rioja. T. I. op. cit., p. 349. GUTIÉRREZ PASTOR, I., MOYA VALGAÑÓN, J. G., RAMÍREZ MARTíNEZ, J. M.a , RAMÍREZ MARTíNEZ, J. M., RUIZ- 
situación a la salida del pueblo, quizá fuera originalmente una cruz de término o cruz terminal, siendo su función la de indicar el límite jurisdiccional.

El templete está construido en sillería, es de planta cuadrangular y está formado por cuatro estribos o pilares rectangulares en diagonal con decoración de bolas en el remate de sus plintos y en la cornisa superior que rodea su perímetro. Es curioso que entre las bolas de la cornisa del contrafuerte noreste puede distinguirse una concha o venera. Dichos contrafuertes soportan otros tantos arcos apuntados doblados y bóveda de crucería de terceletes.

El crucero propiamente dicho está compuesto por un pilar de ángulos achaflanados o fuste de planta octogonal levantado sobre cuatro gradas redondas. En realidad es cuadrangular en su tercio inferior, octogonal en la zona central y hexagonal en el tercio superior. En esta zona de arriba es donde se concentra la escultura, que podríamos dividir a su vez en otras tres partes:

- En la inferior, en la cara oriental del hexágono orientada hacia la carretera y el río Cidacos, se halla la figura arrodillada y orante del donante con la cabeza mutilada y sosteniendo un libro abierto. En la cara opuesta, que da a la cabecera de la ermita, aparece su escudo de armas, cuartelado en cruz, que presenta en el primer cuartel una barra o banda que lo cruza en diagonal, en el segundo, un castillo de tres torres con bordura de aspas y veneras o conchas de peregrino, el tercero está partido y contiene trece besantes o roeles dispuestos en tres palos y dos lobos pasantes con presa en la boca (corderos) enmarcados con bordura de aspas, y el cuarto presenta diez corazones o panelas dispuestos en tres palos (Lám. 3).

- Sobre este corto fuste hexagonal se encuentra el nudo del crucero, que tiene también seis lados, y en cada cara, imágenes de apóstoles y santos sobre ménsulas y bajo doseletes en forma avenerada. Llevan sus atributos característicos en una mano y con la otra sujetan, o bien libros, o bien los extremos de sus ropajes. En el lado este, encima del donante, se sitúa San Andrés con la cruz en aspa, y le siguen, dando la vuelta desde el este hasta el norte, otra figura irreconocible por su gran deterioro y falta de atributo, que podría ser otro apóstol, o quizá una mujer, y San Juan Bautista, que aparece como penitente en el desierto sujetando un libro abierto, con cabellos largos y vestido con piel de animal (pelo de camello según el Evangelio) que deja una pierna al descubierto. En el oeste, en el extremo opuesto a San Andrés, encima del escudo, se sitúa Santiago Peregrino con sombrero de ala ancha decorado con la típica concha, amplia capa, bor-

\footnotetext{
NAVARRO PÉREZ, J., Ermitas de La Rioja. Logroño, Caja de Ahorros de Zaragoza, Aragón y Rioja, 1985. SOLANO ANTOÑANZAS, J. M. ${ }^{\prime}$, El valle del Cidacos (cuenca del Ebro). Vol. Il. op. cit., p. 160. MOYA VALGAÑ̃́N, J. G., "El siglo XVI. El Renacimiento. Arquitectura religiosa", op. cit., p. 153.
} 


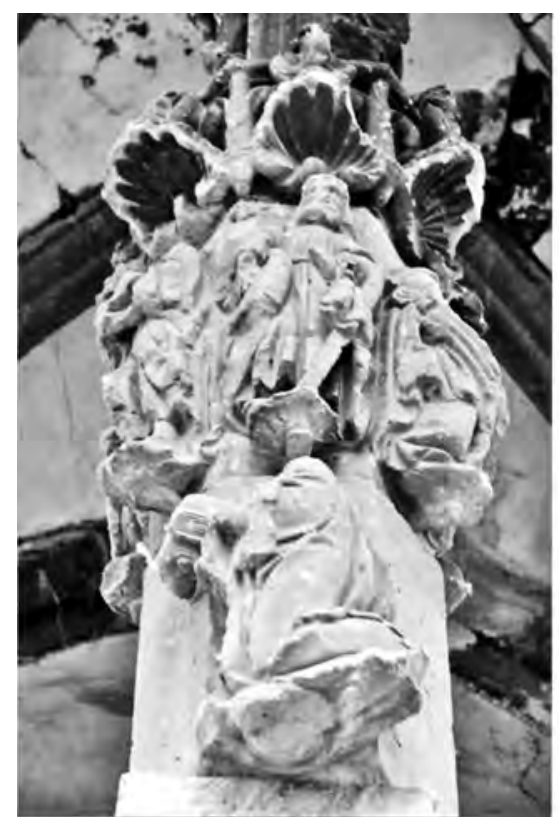

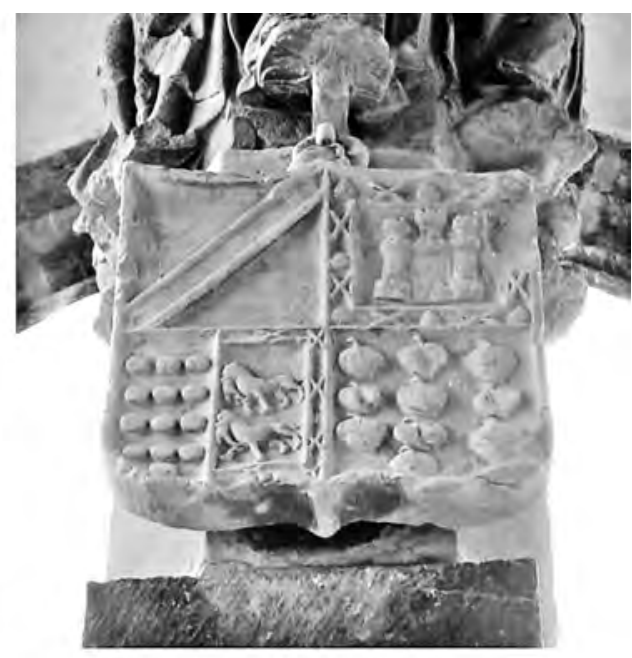

Lámina 3. Esculturas del lado este y oeste del crucero, con la figura del donante y el escudo respectivamente. Fotos Minerva Sáenz y Óscar Reinares.

dón en una mano y libro cerrado en la otra. Por último, en el sur se hallan San Pablo y San Pedro con sus atributos característicos, la espada y las Ilaves respectivamente.

- Encima del nudo se ubica la cruz, que en el anverso, orientado hacia el sur, exhibe un Crucifijo con el Tetramorfos en los ángulos de dicha cruz, y en el reverso, orientado hacia el norte, una Virgen con el Niño.

Tanto la arquitectura del templete como la decoración escultórica del crucero responden al Ilamado estilo Reyes Católicos, y la escultura es de influencia hispanoflamenca, por lo que ambas estructuras deben datarse a comienzos del siglo XVI, hacia 1510 o $1520^{13}$. Estas líneas estilísticas las vemos reflejadas en la decoración de bolas del templete y en la fina decoración escultórica del crucero. La escultura es de buena factura, especialmente el grupo de los apóstoles y santos caracterizados por el naturalismo y la riqueza en el tratamiento de ropajes y atributos. Estas figuras representadas bajo doseletes con remates de veneras son de canon más bien corto, con rostros de pómulos marcados y líneas del cabello tratadas en bucles ondulados. En ellas se acentúa la expresión del detalle hasta la anécdota, esculpiéndose las botonaduras en los ropajes, como

13. MOYA VALGAÑÓN, J. G., "El siglo XVI. El Renacimiento. Arquitectura religiosa", op. cit., p. 153. 
el broche de la capa de Santiago, o las diferentes páginas de un libro, como el que sostiene la imagen de San Pedro. Les caracterizan también los pliegues de los mantos recogidos sobre los brazos en plegados anchos, que caen buscando diagonales con un cierto sentido del movimiento.

El Crucificado, como es usual en la época, es un Cristo desnudo, con ligero estudio de la anatomía, y de tres clavos, pues los dos pies se sujetan a la cruz con un solo clavo. Para que el pie derecho se coloque sobre el izquierdo, que es lo más común, las piernas exhiben una postura un tanto forzada ${ }^{14}$. El Tetramorfos o símbolos de los cuatro Evangelistas se representan en los ángulos de la cruz bajo su forma teriomórfica y alada. El gran deterioro que presentan apenan nos permite distinguirlos. La Virgen, como corresponde a los siglos XV y XVI, ya no es sedente y hierática, sino que aparece de pie sosteniendo a su Hijo en el brazo izquierdo. En ella destacan sus ropajes de voluminosos y abultados pliegues, siguiendo la moda: túnica talar sujeta con cinturón de talle alto y manto dispuesto en forma de capa. La figura lleva corona y descansa sobre una peana adornada con una cabeza de querubín o amorcillo alado, motivo típicamente renacentista. Al igual que ocurre con el Crucificado, en los siglos XV y XVI ya se ha desarrollado plenamente esa tendencia a la humanización que había comenzado en el XIII, utilizándose un canon más real y dotando a las figuras de mayor movimiento.

Aunque en la Rioja Baja existen otros cruceros con templete, recogidos por Elena Calatayud Fernández ${ }^{15}$, el de Enciso es el más antiguo. Los más similares y cercanos cronológicamente son los de Munilla, Préjano y Calahorra, de mediados del siglo $\mathrm{XVI}^{16}$, así como el de Muro de Aguas, construido en 1572 según inscripción.

\section{Descripción de la ermita}

La ermita de la Concepción de Enciso también es de comienzos del siglo $\mathrm{XVI}$, como el crucero, y fue construida como prolongación del mismo con mampostería en los muros y sillería en los contrafuertes, esquinazos y vanos ${ }^{17}$.

14. Esta nueva práctica de sujetar a Cristo al madero con tres clavos surge a comienzos del siglo XIII.

15. CALATAYUD FERNÁNDEZ, E., Arquitectura religiosa en La Rioja Baja: Calahorra y su entorno (1500-1650). Vol. I, Logroño, Colegio Oficial de Aparejadores y Arquitectos Técnicos de La Rioja, 1991, pp. 52, 53, 222, 340-342.

16. En Calahorra había dos, el Ilamado "crucero de abajo", que se sitúa en el antiguo camino de Alfaro, cerca de la catedral y del convento de Carmelitas Descalzos, y "el crucero de arriba", desaparecido, que se ubicaba a la salida de la ciudad entre los caminos de Logroño y Murillo. Véase en CALATAYUD FERNÁNDEZ, E., Ibidem, y en MATEOS GIL, A. J., El humilladero de Calahorra. Memoria histórico-artística. Calahorra, trabajo inédito, 2001.

17. Esta ermita se cita en MOYA VALGAÑÓN, J. G., RUIZ EZQUERRO, J. J., Enciso monumental..., op. cit., pp. 82-89. MOYA VALGAÑÓN, J. G. (Dir.), y otros, Inventario... op. cit., pp. 
Por su estructura arquitectónica y por sus escasos motivos decorativos, todo ello muy típico del estilo Reyes Católicos, parece coetánea de aquel pero un poco posterior y de carácter más popular o rural. Probablemente, al poco tiempo de construirse el humilladero, que en un primer momento sería exento como es usual en este tipo de monumentos, se decidiría adosarle una ermita de calidad arquitectónica más modesta.

Su planta consta de cabecera cuadrangular y una sola nave más ancha con dos tramos; el primero cuadrangular y el segundo rectangular, cubiertos los tres espacios con bóvedas de crucería de terceletes, que siguen un diseño en la cabecera o presbiterio y otro distinto en los dos tramos de la nave (Lám. 4). En el primer espacio son las típicas con nervios diagonales, ligaduras y terceletes, los cuales dan lugar a cinco claves, la central o de la propia bóveda, y otras cuatro laterales en la intersección de los terceletes y las ligaduras. Las dos bóvedas de la nave tienen los nervios diagonales dispuestos de igual modo, pero solo hay terceletes hacia los lados norte y sur ya que en el este y oeste desaparecen, y son las ligaduras las que se prolongan en dirección este y oeste a modo de nervios transversales hacia el arco triunfal y hacia los fajones. De este modo, en vez de tener cinco claves, estas bóvedas solo cuentan con tres, la central y las dos que unen las ligaduras con los terceletes. Las claves y los nervios de las tres bóvedas del templo han llegado a nuestros días con una policromía en vivos colores formando círculos concéntricos, flores de seis pétalos y estrellas de ocho puntas.

Estos abovedamientos apoyan sobre ménsulas y grandes pilastras trapezoidales, lo que proporciona una forma curiosa a la planta, pues esos fuertes apoyos hacen que los tramos adquieran casi forma poligonal, sobre todo los de la nave. En la cabecera los nervios descansan sobre dos ménsulas de forma convexa en las esquinas del muro este; sin embargo, las nervaduras de las bóvedas de la nave mueren en el muro sin ningún elemento de apoyo, muy remarcadas por la policromía.

Los cuatro arcos torales de la cabecera son apuntados, pero tanto el arco triunfal que separa cabecera y primer tramo de la nave, como el arco fajón que separa los otros dos tramos, son rebajados, lo que quizá indique que el modelo gótico empleado en esta ermita se acabó utilizando de modo arcaico o retardatario en una época ya más avanzada para ese estilo artístico. Estos arcos rebajados continúan por los muros hasta apoyar en un banco corrido que se adosa a todo el perímetro interior.

En cuanto a decoración monumental, es un templo muy austero, pues el único motivo ornamental son las bolas que adornan la rosca del arco triunfal, simi-

102, 103. ABAD LEÓN, F., "Geografía Mariana de La Rioja”. op. cit., p. 203. MARTíN LOSA, F. (Dir.), y otros, Enciclopedia de La Rioja. T. I. op. cit., p. 349. AAVV, Ermitas de La Rioja. op. cit. MOYA VALGAÑÓN, J. G., "El siglo XVI. El Renacimiento. Arquitectura religiosa", op. cit., p. 153. 

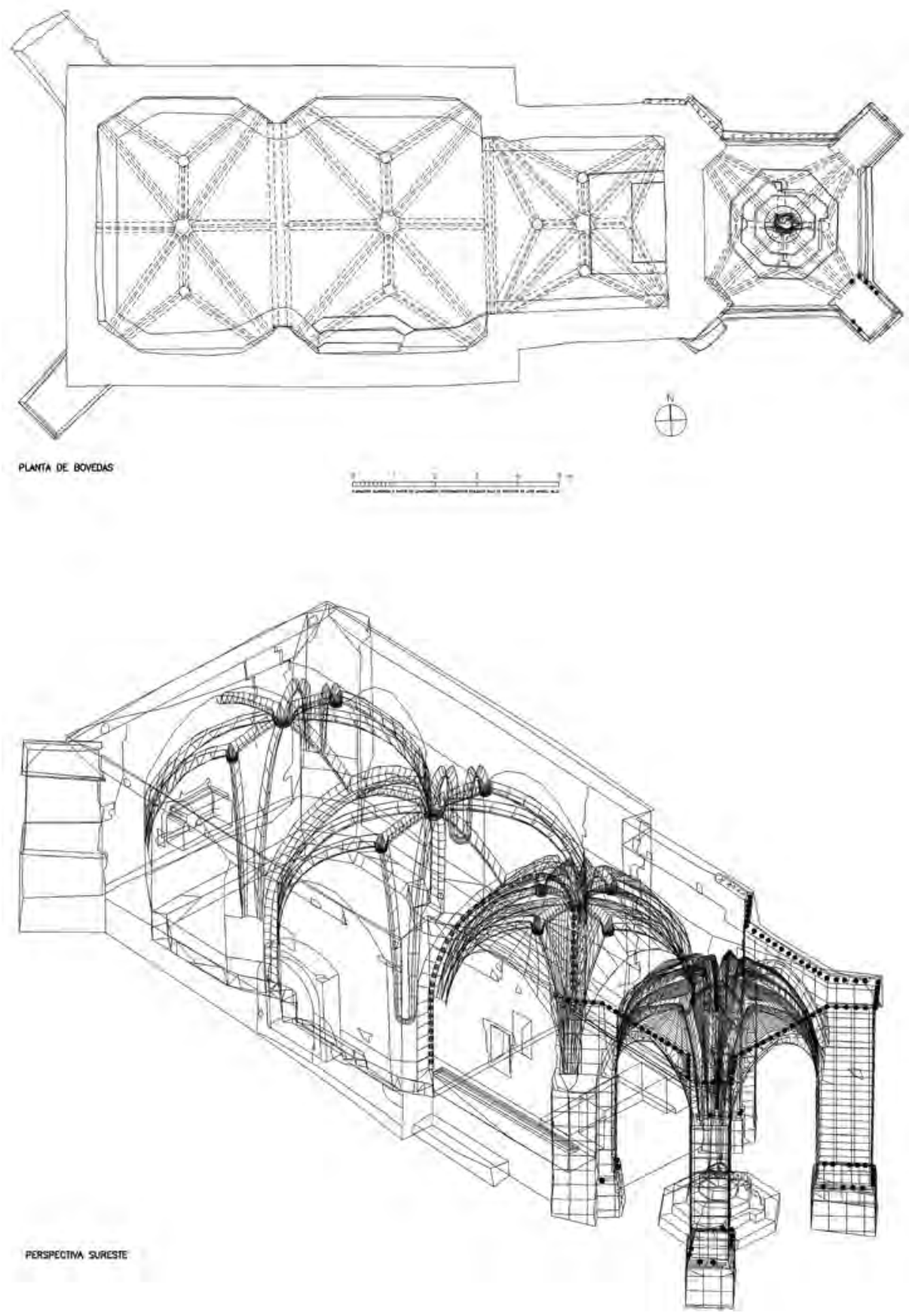

Lámina 4. Planta y perspectiva del crucero y ermita de la Concepción en Enciso. Óscar Reinares. 


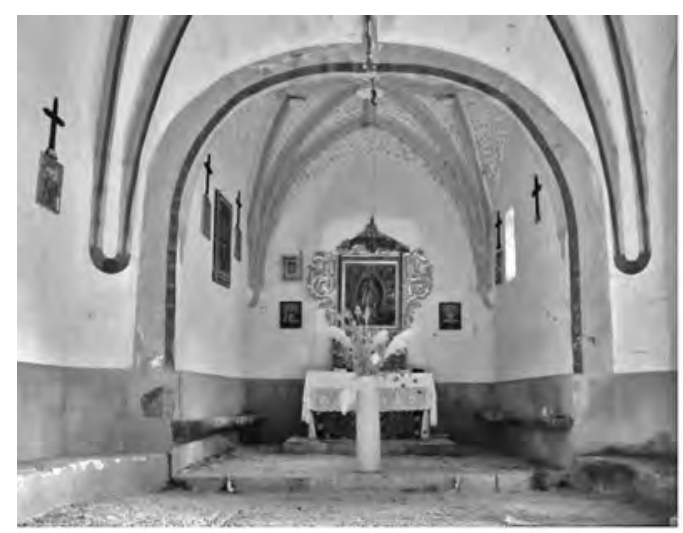

Lámina 5. Vista del interior de la ermita antes y durante la restauración. Fotos Óscar Reinares.

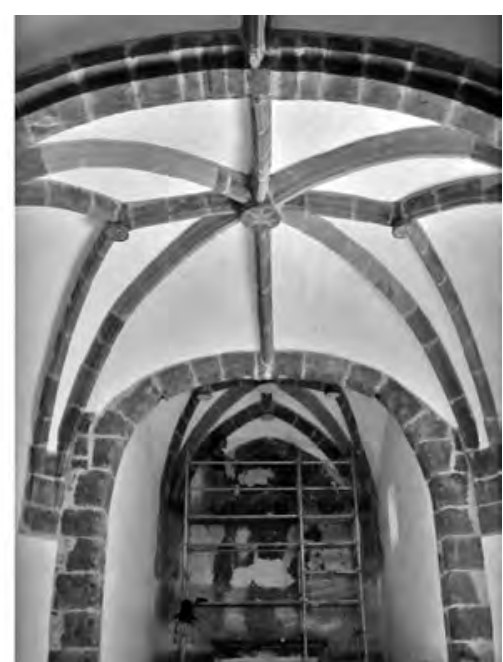

lares a las del remate de la cornisa del templete del crucero y a las de la base de sus contrafuertes, excepto en su policromía, pues han llegado a nuestros días pintadas de granate. Al igual que este arco, tanto los muros como las bóvedas (plementería, nervios y claves) se policromaron en época posterior a su construcción con colores muy intensos y "chillones" (ocres, rojizos, azules), lo cual confería a la ermita un aspecto peculiar (Lám. 5).

Sin embargo, el solado o pavimento es el original, contemporáneo del edificio del siglo $\mathrm{XVI}$, de trazado decorativo, pues muestra un bello empedrado con diseños del Gótico tardío, haciendo dibujos en forma de flores y espirales remarcados en grandes recuadros, uno de los cuales, hacia el lado oeste, posee otros doce cuadrados inscritos con extraños diseños geométricos. Su limpieza y reparación fue llevada a cabo por la empresa En Piedra Viva.

En cuanto a los alzados (Lám. 6), el ingreso se sitúa al sur en el primer tramo de la nave y es de medio punto, remarcado al exterior con dovelas de sillería. El edificio tiene otros huecos o vanos rectangulares que se ubican, uno al sur de la cabecera también enmarcado con sillería, y otros dos de reducido tamaño al sur de la nave, uno encima de la portada en el primer tramo y otro en el segundo. En el muro oeste existen huellas de otro hueco, hoy cegado, que originalmente pudo servir para que los fieles que se acercaban hasta allí pudieran, después de rezar en el humilladero, visualizar el altar mayor con el retablo dedicado a la Virgen, elemento presente en estas ermitas-humilladero.

$\mathrm{Al}$ exterior destacan cuatro poderosos contrafuertes colocados en diagonal, como los del templete del crucero, dos en las esquinas de la cabecera al este y otros dos en los ángulos del hastial occidental. Los muros están recrecidos en su remate, pues en un momento posterior a su construcción se decidió unificar 
ROSANA FONCEA LÓPEZ - MINERVA SÁENZ RODRÍGUEZ

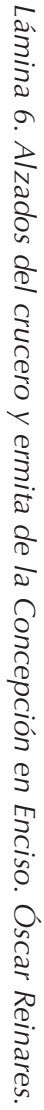

\begin{tabular}{l} 
ह \\
兽 \\
\hline
\end{tabular}

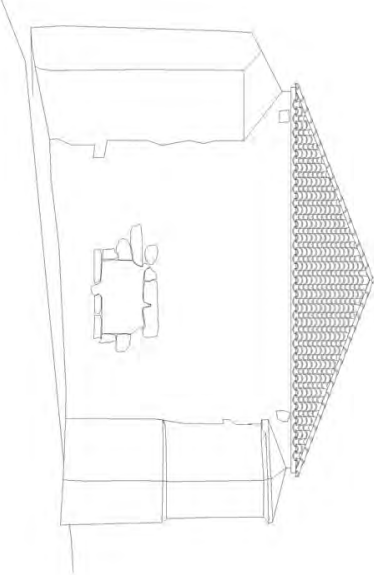

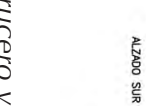
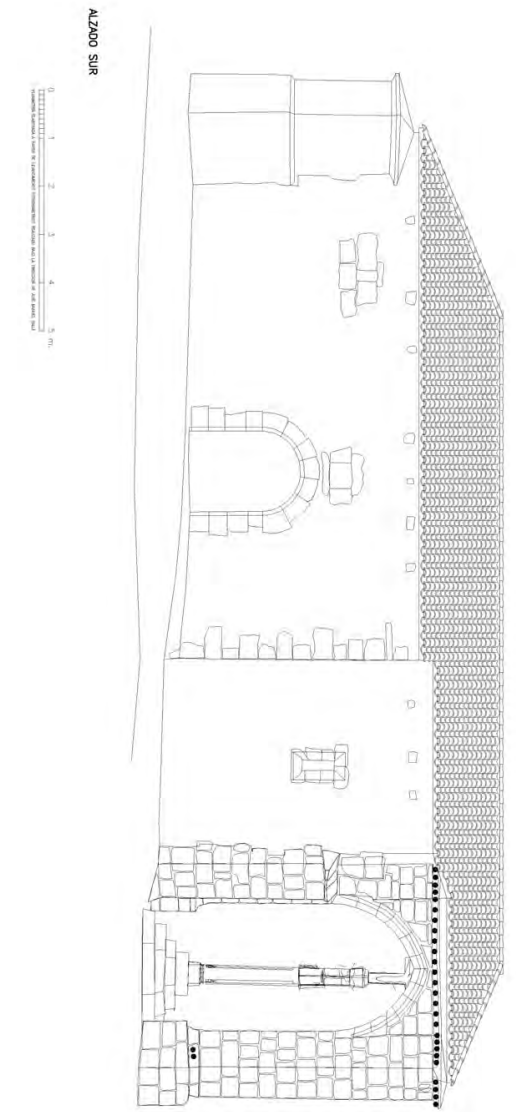

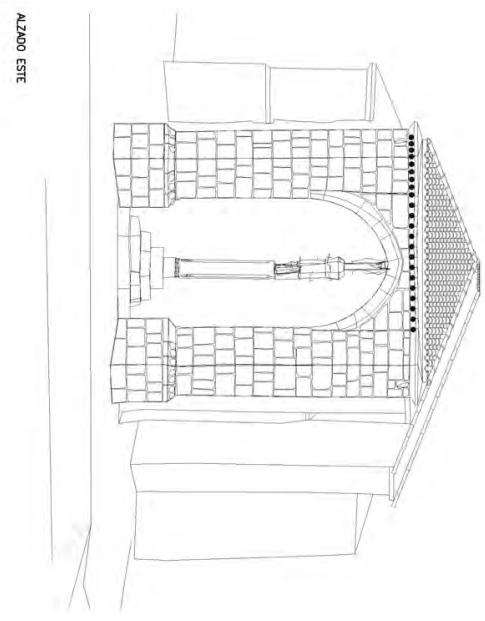

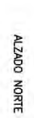

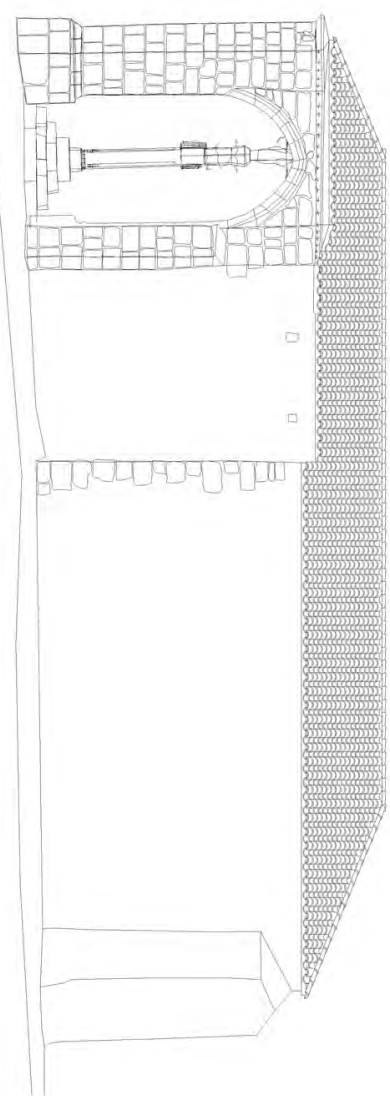


todas las cubiertas (crucero, cabecera y nave) y se tuvieron que igualar las alturas, elevando sobre todo los paramentos de la cabecera con el fin de alcanzar una cumbrera común y proporcionar esa igualdad de cubiertas con la que el edificio llegó al siglo XX. Estas son de teja cerámica de perfil árabe a cuatro aguas.

\section{Una aproximación a los comitentes del crucero}

Existen razones para atribuir la construcción del crucero a un comitente perteneciente a la nobleza. La figura del donante, cuya identidad ha sido siempre una incógnita, está representada de rodillas y en actitud orante en el fuste, bajo las imágenes de San Andrés y del Crucifijo. Sus armas, que se encuentran en la cara posterior y al mismo nivel que la imagen, son el único testimonio que nos permite una aproximación al patronazgo de esta obra, que parece estar relacionada con los descendientes de los Sarmiento, señores de Enciso, vinculados a partir del siglo XV a la Casa de Medinaceli por política matrimonial (Lám. 3). En torno a esta fundación, José Gabriel Moya Valgañón consideró que podía ser obra de un clérigo, quizá relacionado con los prebendados Enciso de Logroño o Calahorra ${ }^{18}$. Por nuestra parte planteamos la hipótesis de que el promotor que costeó las obras del crucero a comienzos del siglo XVI pudiera ser un descendiente de los señores de Enciso, Diego Gómez Sarmiento y Diego Pérez Sarmiento, abuelo y padre respectivamente de Juana Sarmiento, condesa de Medinaceli por su casamiento con Luis de la Cerda.

Antes de analizar la filiación de las armas que aparecen en el escudo, es oportuno hacer un breve repaso por la genealogía de este linaje. En el siglo XIV Enciso pertenecía a la familia noble de los Sarmiento, dueña de un señorío integrado por el sector occidental castellano de la Sonsierra, concedido por Enrique II de Trastámara en $1370^{19}$. Enciso había sido donado por Juan I a su Repostero Mayor, Día o Diego Gómez Sarmiento, casado con Leonor de Castilla. Tras su muerte en 1385, el rey ordenó al concejo de Enciso el 1 de marzo de 1386 que tomara por señores a sus herederos ${ }^{20}$. El señorío de Enciso lo heredó su hijo Diego Pérez Sarmiento, Repostero Mayor de Juan II y Adelantado Mayor de Galicia († 1408 ¿?), casado con Mencía López de Zúñiga (o Estúñiga). Después fue

18. MOYA VALGAÑÓN, J. G., "El siglo XVI. El Renacimiento. Arquitectura religiosa", op. cit., p. 153.

19. La concesión de este señorío es confirmada por Juan I en 1379 y por Juan II en 1414 y 1420 y, a partir de 1470, los Sarmiento se convierten en condes de Salinas, integrando también el señorío del ducado de Híjar. GRANADO HIJELMO, I., La Rioja como sistema. Vol. III. La identidad Riojana. Logroño, Gobierno de La Rioja, 1993, p. 1347.

20. PARDO RODRÍGUEZ, M. aㅡ., Documentación del Condado de Medinaceli (13681454). "Colección Temas Sorianos, no 24", Soria, Diputación Provincial de Soria, 1993, doc. núm. 92, pp. 240-241. (Archivo del Ducado de Medinaceli: ADM. Sección Medinaceli, legajo no 46-72). 
la hija de ambos, Juana Sarmiento, quien recibiría el señorío de Enciso tras su boda con Luis de la Cerda, III conde de Medinaceli. El origen de este condado fue una donación de Enrique II en 1368 con jurisdicción incorporada, siendo el territorio comprendido la villa de Medinaceli y ciento siete aldeas, Ilamadas en los documentos "el común" de Medinaceli²1.

Una de las adquisiciones más importantes del condado de Medinaceli sería precisamente Enciso, que junto a Barca, Fresno y Mandayona aportó Juana Sarmiento como dote en su matrimonio. Sin embargo, no sería hasta el 26 de septiembre de 1433, de acuerdo con su hermano Pedro Sarmiento, cuando Juana tomó posesión de la villa, según refiere una carta de aquél al concejo de Enciso. En el testamento de Juana Sarmiento, dado el 27 de enero de 1435, poco antes de morir, esta entrega la villa de Enciso a su primogénito Gastón, junto al resto de posesiones. Al ser su marido Luis de la Cerda el albacea testamentario, será él quien aparezca como directo tenedor de estas villas ${ }^{22}$.

Pero el 3 de marzo de 1441, debido a la relativa lejanía de Medinaceli y a los problemas políticos del momento, Luis de la Cerda decide dar Enciso en tenencia a su amigo y a su vez primo carnal de su mujer, Juan Ramírez de AreIlano, III señor de los Cameros, quien le presta entonces pleito-homenaje ${ }^{23}$. Los Arellano eran uno de los bandos nobiliarios que entre los siglos XV y XVI se encontraba en un conflicto permanente con los Manrique y los Velasco para conseguir la hegemonía en el territorio riojano ${ }^{24}$. Lo que desconocemos es por qué razón, Juan Ramírez de Arellano solo ejerció su poder sobre Enciso durante apenas un año, ya que el 26 de enero de 1442, Gastón de la Cerda, IV conde de Medinaceli, toma el poder efectivo sobre Enciso, Barca y Fresno a través de su criado Luis de Aguilera, cinco años antes de la muerte de su padre Luis de la Cerda $(\dagger 1447)^{25}$

Gastón († 1454), que hereda de su padre la Casa de Medinaceli y de su madre la villa de Enciso, casó con Leonor de la Vega y Mendoza, hija del marqués de Santillana y señora de Cogolludo, con quien tuvo tres hijos. A Luis de la Cerda, el primogénito, le correspondió heredar la mayor parte de los bienes del mayorazgo, y entre otros muchos bienes partibles la villa de Enciso y Aymón.

Luis de la Cerda (1438-1501) obtuvo el título de I duque de Medinaceli en 1479, por los servicios prestados a Isabel la Católica en su lucha contra Juana la

21. PARDO RODRÍGUEZ, M. ${ }^{\mathrm{a}}$ L., op. cit., pp. 25-28.

22. PARDO RODRÍGUEZ, M. ․ L., op. cit., doc.161, p. 361; doc.164, pp. 379-380; doc.165, p. 381.

23. PARDO RODRÍGUEZ, M. L., op. cit., docs. núm. 178, 180, 181; pp. 421, 422-424.

24. DIAGO HERNANDO, M., "El poder de la nobleza en los ámbitos regionales de la Corona de Castilla a fines del Medievo: las estrategias políticas de los grandes linajes en La Rioja hasta la revuelta comunera". Hispania, Revista Española de Historia, Vol. LXVI, núm. 223, Madrid, Consejo Superior de Investigaciones Científicas, mayo-agosto 2006, p. 511.

25. PARDO RODRÍGUEZ, M. ․ㅡ. L., op. cit., doc. núm. 184, pp. 433-435; pp. 27, 29-30. 
Beltraneja. Aquí comenzó el mayorazgo de los duques de Medinaceli sobre la villa de Enciso, la cual, junto con sus aldeas, fue motivo de pleitos entre sus sucesores, concretamente entre su primogénito Juan de la Cerda, II duque de Medinaceli (1485-1544) por un lado, y sus hermanos Alonso, Pedro y Juana por otro. Este pleito finalizó cuando se consiguió que Alonso de la Cerda, que era señor de Enciso († después de 1543), renunciase al señorío a favor de su hermano mayor a cambio de 200.000 maravedíes de juro de heredad situados en Cogolludo ${ }^{26}$.

A finales del siglo XV y en el XVI la casa de Medinaceli gozaba de importantes rentas proporcionadas por sus señoríos jurisdiccionales, lo cual propició una labor de mecenazgo artístico por parte de alguno de sus miembros. Los duques promovieron diferentes e importantes obras en las que intervinieron arquitectos vinculados a la familia que aportaron las innovaciones del estilo renacentista. Por ejemplo, Luis de la Cerda y de la Vega, I duque de Medinaceli, ejerció como promotor artístico, encargando a Pero de Cubillas importantes obras en algunas villas de su señorío como Cogolludo (Guadalajara) y El Puerto de Santa María (Cádiz). Aunque el pequeño señorío de Enciso estaba alejado de las grandes influencias artísticas que promovieron estos duques, consta que este cantero intervino por encargo ducal en el castillo de Enciso en 1521, en una fecha aproximada a la construcción del crucero y la ermita de la Concepción ${ }^{27}$. Lo que no consta es si intervino en este edificio, que indudablemente se estaría terminando de construir por esos años.

Los descendientes del ducado de Medinaceli fueron señores de Enciso hasta época moderna. Existe una noticia del siglo XVII, que podemos considerar anecdótica, sobre la relación del pueblo de Enciso con estos duques. Durante años el cabildo realizó una recaudación de limosnas para construir el retablo de la Vir-

26. DIAGO HERNANDO, M., La Extremadura Soriana y su ámbito a fines de la Edad Media. T. I. Madrid, Universidad Complutense, 1992, p. 108.

27. Pero de Cubillas fue un maestro de cantería de posible ascendencia cántabra o montañesa, documentado entre 1496 y 1525, y vinculado a la ejecución de obras de carácter militar ordenadas por los duques de Medinaceli en sus señoríos jurisdiccionales de Castilla. Después de este importante periodo como maestro de obras al servicio de la casa ducal de Medinaceli entre 1496 y 1521, se documenta trabajando en la catedral de Segovia hacia 1525 con otro cantero Ilamado García de Cubillas, que aparece entre 1525 y 1560 . A juzgar por lo que Pero de Cubillas realizó en sus obras, parece un arquitecto que destacó en construcciones defensivo-militares, y ello queda demostrado en su intervención en el castillo de Enciso, el cual, debido a sus lejanos orígenes en el siglo X, necesitaba urgentes reformas a comienzos del XVI. En 1521 Pero de Cubillas ofrece un informe de las mismas, centradas sobre todo en la torre del homenaje. Propone reformarla en cantería manteniendo su altura y rematándola con canes, almenas y pretil, y también sugiere construir cuatro cubos con troneras y una portada de cantería "para que sea una de las mejores fortalezas que aya en la frontera" y para que "desta manera quedara la mejor fortaleça que pueda aver en estas partes". Se compromete, por el sistema a destajo y cobrando 100.000 maravedís, a terminar la obra el día de San Miguel de 1521. Véase en ROMERO MEDINA, R., "Un cantero tardogótico de posible ascendencia cántabra en Castilla: Maese Pero de Cubillas (1496-1525)", Laboratorio de Arte, núm. 19, 2006, pp. 49-66. 
gen de la Estrella. El pueblo quiso colocar el escudo de los duques de Medinaceli en un lugar principal del nuevo retablo que había costeado, y que realizó Sebastián del Ribero, pero se encontró con la oposición del cabildo parroquial, que en 1653 pedía al obispado su intervención para impedir su colocación ${ }^{28}$.

En el escudo del crucero de la Concepción no aparecen las armas del linaje de los Medinaceli o de la Cerda, cuyo blasón es cuartelado con el primer y cuarto cuartel partido de Castilla y León (castillo de tres torres y león), y el segundo y tercero con las Uses de Francia (flores de lis). Sin embargo, está identificada la rama de los Sarmiento en el tercer cuartel del escudo de Enciso, que es partido, con trece besantes dispuestos en tres palos, y dos lobos pasantes con corderos en la boca enmarcados con bordura de aspas. Los trece besantes o roeles de oro en campo de azur dispuestos en tres palos corresponden al linaje Sarmiento ${ }^{29}$, y así aparecen en el cubo sudeste del castillo de Fuentes de Valdepero (Palencia), de mediados del siglo XV y comienzos del XVI, que perteneció a Diego Pérez Sarmiento, Adelantado Mayor de Galicia y padre de Juana Sarmiento, y en el crucero de Salinas de Añana (Álava), ya que los Sarmiento fueron también condes de Salinas ${ }^{30}$. Algunos años después, en la época de construcción de la ermita de la Concepción, podemos constatar de nuevo la vinculación matrimonial de Ios Sarmiento con los de la Cerda: Gastón de la Cerda (1504-1552), III duque de Medinaceli, estuvo casado con María Sarmiento de la Cerda, aunque de esta unión no hubo descendencia.

La presencia de estas armas en el escudo sugiere que los comitentes del crucero tuvieron que estar vinculados a la descendencia de Luis de la Cerda y Juana Sarmiento. De haber existido en Enciso una arquitectura civil significativa ornamentada con escudos, se hubiera abierto una línea de investigación sobre las familias procedentes de la nobleza local, que acaso hubiera permitido conocer la familia concreta a la que pertenecen las armas que nos ocupan, pero no existen en su casco urbano restos destacables de antiguas edificaciones. En el escudo de Enciso, aparte de estar claramente identificada la rama de los Sarmiento, se muestran las armas de otros linajes emparentados con ellos y sus descendientes, como los Zúñiga, los Mendoza, los López de Haro, los Avellaneda y los Hurtado de Mendoza ${ }^{31}$.

28. AHPLR, Juan García de la Plaza, leg. 1569, año 1653, fol. 54.

29. GONZÁLEZ DORIA, F., Diccionario heráldico y nobiliario de los reinos de España. Madrid, ed. Bitácora, 1987, p. 743.

30. MARTíNEZ, E., Cruceros en Álava. Vitoria-Gasteiz, Diputación Foral de Álava, Servicio de Publicaciones, 1989, p. 90.

31. Sería prolijo desarrollar los vínculos entre estos linajes, excediendo los límites de este artículo. Su desarrollo se encuentra en el informe que realizamos sobre el edificio durante su restauración: FONCEA LÓPEZ, R., SÁENZ RODRÍGUEZ, M., Informe histórico-artístico del crucero y ermita de la Concepción en Enciso (La Rioja). 2008, inédito. 


\section{Proceso constructivo del crucero y la ermita}

La información documental existente es bastante posterior al origen de este monumento. Las visitas realizadas a los edificios religiosos por un encargado episcopal están contenidas en los Libros de Fábrica de las iglesias de Enciso, dando fe del estado y necesidades de parroquias y ermitas. En 1553 Francisco lbáñez, visitador general del obispado, manifestaba su preocupación por el trato que recibían estas últimas, no tanto por su estado material como por el mal uso de carácter moral que a su juicio hacían de ellas, "los moços y moças y otras personas que ballan y dançan en las dichas hermitas y hazen otras deshonestida$\operatorname{des}^{\prime \prime 32}$. Como consecuencia, la Iglesia prohibía cualquier actividad profana en dichas ermitas como el baile o el juego, bajo pena máxima de excomunión. En este documento no se especifica el nombre de ninguna de ellas, sino que se refiere a todas en general.

Desde su origen y por sus funciones, la ermita de la Concepción era un edificio modesto que formaba parte del conjunto de otras seis ermitas, entre las que primaba en importancia la de San Esteban, junto a las iglesias de las aldeas de la jurisdicción de Enciso y los dos templos de San Pedro y Santa María de la Estrella que coexistían en la villa. Por eso no debe extrañar la falta de atención que padecía la ermita, que atravesó épocas de abandono al no poseer bienes adscritos a ella que produjeran rentas y al competir en necesidades con edificios de mayor importancia y uso. De ahí que una vez construida, debió permanecer largo tiempo sin que se produjeran en ella reformas importantes, pues la documentación del siglo XVI solo permite constatar gastos en diferentes obras en las iglesias parroquiales de Enciso y en las que estaban contenidas en su ámbito eclesial. En ocasiones también aparecen gastos por obras menores pagadas a operarios en las que no se especifica el edificio de que se trata.

En el año 1612 el visitador del obispado informaba del peligro que corría la ermita porque se hacía fuego en el humilladero: "Otrosi atento le conto que en el umilladero de la Conceción se ace lumbre de que podria resultar mucho dano asi al umilladero como a la hermita que le esta pegante" ${ }^{\prime \prime 3}$. El visitador Francisco Polo promulgaba una pena que podía hacer efectiva cualquier beneficiado de las iglesias de Enciso, a quien debían pagar dos reales si se incumplía la norma de no hacer fuego ${ }^{34}$.

Las noticias en los años 1761, 1766, 1771 y 1784 sobre el edificio aluden de forma general a aspectos de mantenimiento de objetos litúrgicos y a la seguridad de su espacio, insistiéndose en las penas de excomunión mayor para quienes abrieran violentamente sus cerraduras o dejaran dentro cosas no relacionadas con

32. AHDLO. Enciso. Libro de Fábrica de la Estrella, 1548-1590. Caja 13, fols. 35 oo 37 ro․

33. AHDLO. Enciso. Libro de Fábrica de la Estrella, 1591-1674. Caja 13, fol. 67 ํo.

34. Ibidem. 
el propio adorno de las ermitas. Estas recomendaciones solían ser comunes para todas las ermitas de la diócesis, por lo que hay que pensar que quizá muchos de estos edificios pasaran por momentos de abandono o permanecieran abiertos o utilizados como almacén. Los visitadores de esos años (Antonio Toranzo y Hontañón, José Mateo López y Francisco Alonso Gutiérrez) insisten en que no debían introducirse cosas impropias del lugar sagrado que era, y se instaba a los curas beneficiados a que la mantuvieran con el debido aseo y la surtieran de lo necesario para celebrar las misas ${ }^{35}$. Precisamente, en esos años se ordenaba realizar un pórtico (1761) y enladrillar el suelo (1766) en San Esteban, ermita cercana de la que hoy, lamentablemente, solo pueden verse sus ruinas ${ }^{36}$.

A finales del siglo XVIII se realizaron determinadas obras en la Concepción, aun cuando no se especifique el carácter de las mismas. En 1797 el obispo Francisco Mateo Aguiriano visitó los edificios religiosos de Enciso, y entre ellos la ermita en la que, según se afirma, se estaba "componiendo y reparando de lo necesario", por lo que ordenaba que se continuaran las obras hasta terminarlas, dejándola "con la debida perfección" para que se pudiera celebrar el culto, que exigía adornar el altar con su ara y proveerlo de tres manteles, candeleros, una cruz con crucifijo, frontal, y sacras ${ }^{37}$. En estas obras ejecutadas a partir de 1797 pudo planificarse la reforma de uno de los contrafuertes que se adosan al oeste de la ermita, concretamente el del ángulo sudoeste, y quizá la pequeña hornacina sobre la puerta de ingreso. También podría ser de este momento la decoración de la mesa de altar, a la que enseguida aludiremos.

En el año 1820 el visitador Juan Inocente Romero encontraba la ermita con el testero ruinoso y las bóvedas muy sucias. La causa por la que "la pared del altar mayor estaba quebrantada" la atribuyó a los terremotos, y ordenó que se reparase y que se lucieran las bóvedas junto a dicha pared ${ }^{38}$. Es posible que se realizara en aquel momento la pintura decorativa que presenta la ermita en el paño frontal de la cabecera, y en las claves y nervios de las bóvedas. El terremoto al que se refiere el documento causante de los daños en la ermita, debió ser el que se originó tres años antes de la visita. El 18 de marzo de 1817, un sismo de intensidad VIII sacudió La Rioja, principalmente el área de Arnedo y Préjano, extendiéndose hasta Ausejo, Calahorra y Logroño ${ }^{39}$.

35. AHDLO. Enciso. Libro de Fábrica de la Estrella, 1753-1797. Caja 14, fols. 71 ํo-72 rº.; fol. 99 vo; fol. $150 \mathrm{r}^{\circ}$ y $v^{\circ}$.

36. AHDLO. Enciso. Libro de Fábrica de la Estrella, 1753-1797. Caja 14, fol. 34 ํo-35 ro․

37. AHDLO. Enciso. Libro de Fábrica de la Estrella, 1753-1797. Caja 14, fols. 274 ํo, 277 ro .

38. AHDLO. Enciso. Libro de Fábrica de la Estrella, 1797-1878. Caja 15, fols. 111 ํo, 113 ํo, 114.

39. MARTíN ESCORZA, C., "El sismo de 18 de Marzo de 1817 en La Rioja". Kalakorikos, 10, Calahorra, Amigos de la Historia de Calahorra, 2005, pp. 327-334. 
El visitador también encontró abandono general en los bienes muebles que poseía la ermita: "por lo qual manda su ilustrisima a las personas obligadas a la conservación de dicha hermita que inmediatamente pongan en el altar un ara consagrada, las sacras correspondientes y una cruz con la necesaria elevación".

En 1828 el visitador Romualdo Mendoza recorría algunas ermitas de Enciso para dejar constancia de su estado, pero no entraba en la Concepción, por lo que suponemos que se habían Ilevado a cabo las reformas de $1820^{40}$.

El 25 de febrero de 1844, en una estadística realizada por el obispado en el arciprestazgo de Arnedo, al que pertenecía Enciso, se cita la ermita de Nuestra Señora de la Concepción como una de las siete situadas extramuros de la villa, las cuales también se nombran (San Esteban, San Cristóbal, San Juan Bautista, San Andrés, Santa Bárbara y Nuestra Señora del Campo), especificándose que "todas ellas tienen culto público en determinados días del año, y son de propiedad de la villa, excepto la ultima, que se cree ser de propiedad del Excelentisimo Señor Duque de Medinaceli" ${ }^{41}$.

Según otra estadística de 1885, sólo quedaban en Enciso cuatro ermitas (San Juan, Santa Bárbara, San Esteban y la Concepción), con un altar en cada una, habiendo culto durante ciertos días en todas ellas menos en la de Santa Bárbara. La titularidad de las cuatro se compartía a entendimiento entre el municipio y la iglesia pero se especificaba que "hay otra también inculta que fue de patronato de Medina Celi", refiriéndose -aunque no se nombra-, a la de la Virgen del Campo ${ }^{42}$.

Las noticias documentales existentes sobre el crucero y ermita de la Concepción son tardías respecto a las fechas del inicio de su construcción, y escasamente reveladoras, como hemos visto, de manera que un acercamiento a sus orígenes ha de basarse fundamentalmente en análisis estilísticos y arqueológicos.

Desde un análisis estilístico general, la arquitectura y escultura del crucero y la ermita remiten de forma evidente a los primeros años del siglo XVI, pero además, la observación del edificio y el análisis arqueológico, junto con los datos documentales obtenidos a partir del siglo siguiente a su construcción, permiten concretar, como se verá, que hubo al menos dos secuencias en la realización del proyecto original y algunas reformas posteriores.

Las dos partes de este monumento, diferenciadas estructuralmente, pertenecen estilísticamente a la época del Gótico tardío y del Renacimiento, las cuales en este caso arrancan de lo hispano-flamenco, plasmado especialmente en la escultura del crucero. Y aunque las formas arquitectónicas e incluso los motivos decorativos de la escultura monumental de ambas estructuras son los mismos -medias esferas-, el crucero parece algo anterior a la ermita, pues los

40. AHDLO. Enciso. Libro de Fábrica de la Estrella, 1797-1878. Caja 15, fol. 160.

41. ADC. Sección Estadísticas. Arciprestazgo de Arnedo. Enciso y su tierra. Sign. 6/453/3.

42. ADC. Sección Estadísticas. Arciprestazgo de Arnedo. Parroquia de Enciso. Sign. 6/471. 
muros de esta apoyan sobre los estribos de aquel. Su trazado adquiere mayor relevancia constructiva, tal vez porque fue objeto de un primer y único proyecto costeado por un comitente de la nobleza, y posiblemente entonces la ermita no estaba ni siquiera proyectada. Y como el crucero parece más cercano cronológicamente a la cabecera que a la nave de esta, es lógico pensar que la ermita se construiría inmediatamente después en una sola fase, de este a oeste.

El análisis de los elementos constructivos, como bóvedas o apoyos, también nos permite una aproximación a la cronología del edificio, en relación con otras estructuras similares coetáneas. Las bóvedas sobre arcos apuntados del humiIladero y de la cabecera de la ermita son de nervios diagonales, terceletes rectos y ligaduras entre las claves de estos, propios del estilo Gótico. Este modelo de bóveda corresponde a una época temprana del siglo XVI, que en La Rioja se encuentra en algunos templos no anteriores a $1480^{43}$. Terceletes cuyos nervios tienen la misma sección que los de la cabecera y crucero de Enciso encontramos desde finales del $X V$ en diversos templos de la región. En la propia localidad de Enciso se empezaba a construir por la misma época que el humilladero y ermita de la Concepción, la iglesia parroquial de Santa María de la Estrella, aportando en las cubiertas el tipo de bóveda sencilla de terceletes, que también se halla en el primer tramo y en la antigua sacristía de la iglesia de San Pedro ${ }^{44}$. Este esquema de bóveda es el más sencillo que encontramos en edificios de la Rioja Baja, y nos indica una fecha temprana de la construcción dentro del siglo $\mathrm{XVI}$, llegando a utilizarse hasta mediados de siglo ${ }^{45}$.

Las dos bóvedas de la nave de la ermita de la Concepción son similares a las de cabecera y crucero, con los nervios diagonales dispuestos de igual modo, aunque solo hay terceletes hacia los lados norte y sur, prolongándose las ligaduras a modo de nervios transversales hacia el arco triunfal y hacia los fajones. El mismo modelo se encuentra en las capillas al norte de las naves de la catedral de Calahorra.

Las bóvedas de crucería más tempranas, hasta el primer cuarto del siglo XVI, son todavía algo capialzadas. En Enciso, los cuatro arcos torales de la cabecera son apuntados -y por lo tanto, sus bóvedas lo son un poco también-, pero tanto el arco triunfal que separa cabecera y primer tramo de la nave, como el arco fajón que separa los otros dos tramos, son rebajados, y sus bóvedas, algo más planas.

En cuanto a los apoyos, las bóvedas se sostienen en ménsulas y grandes pilastras trapezoidales, y sus nervios descansan en la cabecera sobre dos mén-

43. MOYA VALGAÑÓN, J. G., Arquitectura religiosa del siglo XVI en La Rioja Alta. T. I, Logroño, IER, 1980, pp. 21-31, 50.

44. MOYA VALGAÑ́́N, J. G. (Dir.), y otros, Inventario artístico de Logroño y su provincia. Tomo II: Cenicero-Montalbo en Cameros. Madrid, Ministerio de Educación y Ciencia, 1976, p. 93.

45. CALATAYUD FERNÁNDEZ, E., op. cit., pp. 197, 256, 260, 342, 410. 
sulas de forma convexa en las esquinas del muro este, pero en la nave mueren en el muro sin ningún elemento de apoyo, lo que nos remite también a una cronología del primer cuarto del siglo XVI.

Junto a los elementos estructurales, la decoración anuncia también la época de inicio de la construcción, si bien se trata de una edificación rural, de gran sencillez y austeridad ornamental. Así, las ménsulas del muro este de la cabecera de la ermita son apoyos de perfil convexo, lisas y algo rudimentarias. Las bolas características de la ornamentación del tipo Reyes Católicos de comienzos del XVI, presentes en el arco triunfal de la ermita, en los remates de los plintos de los estribos, así como en la cornisa que rodea el templete, se encuentran también en la misma población, en la cercana iglesia de Santa María de la EstreIla bajo el tejaroz y en un óculo en el brazo del crucero.

El análisis arqueológico realizado por Beatriz Irulegui Blasco ha permitido afirmar que existió un cambio de proyecto en el transcurso de la obra del crucero $^{46}$. Así parecen indicarlo algunos elementos que se analizan en dicho informe y que afectan especialmente a la trabazón de los estribos noroeste y sudoeste del crucero con los muros de la ermita, en cuyos contrafuertes noreste y sudeste se utiliza, no obstante, el mismo tipo de sillar y técnica, posiblemente con el fin de dotar de una mayor homogeneidad a la obra tras el cambio de planteamiento. Los estribos noroeste y sudoeste del humilladero no se rematan igual que los demás y parece como si estuvieran sin terminar de tallar, dando la sensación de ser una obra incompleta. Los enganches de estos dos estribos con los paños norte y sur de la ermita son peculiares, al intentar adaptarse a ella: en el estribo noroeste hay dos piezas que intentan dar continuidad a la obra y luego continúa el estribo con su propio desarrollo, y en el sudeste se aprecian adarajas, es decir, piezas que se dejan preparadas para poder adaptarse al paño meridional de la ermita.

En el hastial occidental se aprecia que los dos contrafuertes son estructuras diferentes, y quizá estén relacionados con problemas estructurales derivados de la mala planificación. No obstante, el contrafuerte del ángulo sudoeste presenta una construcción mejor definida con hiladas más regulares y una imposta que lo divide en dos partes, mientras que el contrafuerte noroeste conserva una construcción más rudimentaria, o menos trabajada, que pudiera ser anterior, y de ahí que planteemos la posibilidad de que el primero fuera reconstruido en las obras de finales del siglo XVIII, al igual que la hornacina de la parte superior del ingreso. En la construcción de ambos contrafuertes se revela una ejecución posterior a la creación de la ermita porque se observa una discontinuidad con respecto a las hiladas de los muros de esta, en la que se aprecia la rotura de sillares que se produjo para embutir los contrafuertes en las fachadas norte y sur, y las juntas de

46. Agradecemos a la arqueóloga Beatriz Irulegui Blasco la información facilitada. 
mortero que traban las piezas de los contrafuertes que montan sobre el mortero de los sillares de la ermita.

Por los resultados obtenidos en las catas arqueológicas realizadas por Beatriz Irulegui se deduce que existió una falta de planificación, pues al parecer, la ermita se levantó sin una cimentación previa o cajeado, lo que causó irregularidades constructivas que afectaron directamente a los muros, los cuales aparecen colgados y resueltos en la base con un banco corrido con el que se trató de ocultar el error.

Los muros de la ermita están recrecidos en su remate en todo el perímetro, porque también en un momento muy posterior a la construcción original, se decidió unificar todas las cubiertas igualando todas las alturas hasta la cota máxima del crucero -cuya bóveda posee una mayor altura que las de la ermita-, ocultando así unas gárgolas que formaron parte de la decoración escultórica original.

Las pinturas aparecidas durante las obras, cuya restauración ha sido llevada a cabo por María Mena Miguel, pertenecen a distintos momentos ${ }^{47}$ (Lám. 5). Se han podido constatar restos de pincelado original de comienzos del siglo XVI en uno de los nervios de las bóvedas (lado del evangelio de la bóveda de la cabecera), que decoraba el recorrido de dicho nervio con una simulación de despieces de sillares en un tono negro. También en la restauración pictórica quedó al descubierto parte de la decoración original que tuvo la ermita a comienzos del siglo XVI. Se trata de pincelados que imitan tanto sillares como ladrillos paralelepípedos blancos sobre base gris. La imitación de sillares apareció en las paredes verticales de los pies y del primer tramo de la nave, tanto en el lado del evangelio como en el de la epístola, y la imitación de ladrillos se halló en la plementería de las bóvedas del primer tramo de la nave en el lado de la epístola, y en la bóveda de la cabecera, tanto en el lado de la epístola como en el del evangelio.

En el testero de la ermita, María Mena Miguel descubrió las pinturas murales con técnica en seco a base de motivos geométricos y vegetales. Pertenecen al siglo XVI y es coetánea al origen de la ermita una capa pictórica del testero en tono gris con pincelado en blanco, simulando despieces de sillares, que solo es visible en el área que ocupaba el retablo mayor, y que se empleaba para dar homogeneidad a los distintos materiales de la fábrica. Otra capa probablemente de finales del siglo XVIII o comienzos del XIX presenta mayor calidad. Recordemos que es en 1820 cuando, según la documentación, se emprenden reformas en la ermita siendo necesaria la renovación de "la pared del altar mayor que estaba quebrantada" ${ }^{\prime 4}$. El ara, que también posee decoración pictó-

47. MENA MIGUEL, M., Informe de restauración interior. Ermita de la Concepción. Enciso, La Rioja. Logroño, 2008, inédito.

48. AHDLO. Enciso. Libro de Fábrica de la Estrella, 1797-1878. Caja 15, fols. 111 ํo, 113 ํo, 114. 
rica, se mandó realizar también en 1820 como queda reflejado en las fuentes ${ }^{49}$. La renovación en aquel momento debió alcanzar también a las bóvedas que, según la documentación, estaban "muy negras", y a las once claves circulares de las bóvedas de crucería, donde se representan flores, estrellas y círculos.

A modo de conclusión podemos apuntar que la importancia del edificio de la Concepción recae especialmente en su crucero, del que ya se ha resaltado su mayor calidad arquitectónica y escultórica con respecto a la ermita. El hecho de que sea el más antiguo que se conserva en La Rioja, y ejemplo casi único con una rica escultura hispanoflamenca, revela también su importancia en el patrimonio artístico de nuestra región. Es muy posible que se mantuvieran relaciones constructivas entre este monumento y el puente sobre el Cidacos también denominado de la Concepción, situado muy cerca y construido por las mismas fechas, pero de nuevo la carencia documental se impone. Junto con los otros puentes de la localidad, se cita desde los siglos XVII al XX, pero en ningún caso se aportan datos que permitan ampliar los ya conocidos sobre la ermita ${ }^{50}$.

49. AHDLO. Enciso. Libro de Fábrica de la Estrella, 1797-1878. Caja 15, fols. 111 º , 113 vo, 114.

50. ARRÚE UGARTE, B., MOYA VALGAÑÓN, J. G. (Coord.), Catálogo de puentes anteriores a 1800. La Rioja. I. Logroño, IER, Ministerio de Fomento, 1998, pp. 578-582. 